\title{
KOMUNIKASI INTERPERSONAL GURU DAN SISWA DALAM MENGEMBANGKAN BAKAT DAN KREATIVITAS ANAK AUTIS DI SLB TAMAN PENDIDIKAN ISLAM (TPI) MEDAN
}

\author{
Syaira Arlizar Ritonga \\ Effiati Juliana Hasibuan \\ Universitas Medan Area \\ syairaarlizar25@gmail.com
}

\begin{abstract}
Abstrak
Autismemerupakan gangguan perkembangan yang terjadi pada masa anak-anak yang ditandai dengan adanya keterlambatan dalam bidang kognitif, bahasa, perilaku, komunikasi, dan interaksi sosial. Adapun informan dalam penulisan ini adalah Kurnia dan Afgan, siswa autis di SLB TPI Medan. Penelitian ini bertujuan mengetahui bagaimana komunikasi interpersonal yang terjadi antara guru dan siswa dalam mengembangkan bakat dan kreativitas anak autis. Penelitian in menggunakan pendekatan kualitatif dengan cara observasi langsung dan wawancara mendalam yang melibatkan guru dan orangtua dari siswa autis sebagai narasumber. Dari hasil penelitian, dapat dikatakan bahwa peran komunikasi interpersonal guru di sekolah sangat penting dalam membantu mengembangkan bakat dan kreativitas siswa autis. Guru juga membantu dalam hal meningkatkan kemampuan komunikasi dan interaksi sosial siswa autis dengan orang lain.Dalam hal ini, peningkatan kreativitas dan kemampuan seorang guru selaku penanggungjawab dan pengontrol segala aktivitas siswa di sekolah juga diperlukan agar dapat mengembangkan kemampuanberkomunikasi serta bakat dan kreativitas yang dimiliki oleh siswa.
\end{abstract}

Kata Kunci: komunikasi interpersonal, autisme, Sekolah Luar Biasa

\begin{abstract}
Autism is a development disorder that occurs in childhood characterized by delays in cognitive, language, behavior, communication, and social interaction abilities. The informants in this research are Kurnia and Afgan, who are students with autism atspecial school SLB Taman Pendidikan Islam Medan. The research aims to know how the interpersonal communication occurs between teacher and students in developing talent and creativity of the children. This research used qualitative approach, carried out with direct observation and in-depth interviews involving teachers and parents of the students. The result shows that interpersonal communication of teacher plays a big role in helping students with autism to develop their talent and creativity. Teacher also helped in improving communication skills and social interaction of student with autism. In this case, upgrading teachers creativity and ability, as a people who are responsible and controller of all of students activties, are also needed in order to develop the communication ability as well as the talent and creativity of the students.
\end{abstract}

Keywords: interpersonal communication, autism, special school 


\section{PENDAHULUAN}

Anak autis adalah kondisi anak yang mengalami gangguan perkembangan fungsi otak yang mencakup bidang sosial, komunikasi verbal dan non-verbal, imajinasi,fleksibilitas, kognisi, dan atensi. Anak autis merupakan anak yang membutuhkan perhatian dan perlakuan khusus dari lingkungan sekitarnya yang berbeda dengan anak normal lainnya. Mereka seperti terbelenggu dengan dunianya sendiri karena mengalami hambatan dalam komunikasi dan interaksi sosial dengan orang lain.

Menurut Leo Kanner (1943), istilah autism berasal dari kata "autos" yang berarti diri sendiri dan "isme" yang berarti suatu aliran. Autis berarti suatu paham yang tertarik hanya pada dunianya sendiri. Autis juga berarti suatu keadaan dimana seorang anak berbuat semaunya sendiri baik cara berfikir maupun berperilaku. Keadaan ini biasanya terjadi sejak usia masih balita dan biasanya terjadi sekitar usia 2-3 tahun. Dimana biasanya pada usia tersebut anak sudah mulai belajar untuk bicara, tapi pada anak yang mengalami gangguan autis mengalami keterlambatan dalam hal interaksi sosial, masalah dalam bahasa yang digunakan, dalam komunikasi sosial dan permainan simbolik atau imajinatif.

Salah satu cara yang dapat dilakukan untuk mengurangi ketidakmampuan anak autis dalam dunia sosial adalah dengan melatihnya untuk melakukan komunikasi interpersonal dengan orang lain. Jika komunikasi yang dilakukan berjalan dengan baik maka akan terwujud interaksi sosial yang baik antara anak autis dengan lingkungan sekitarnya.

Komunikasi interpersonal merupakan proses pertukaran informasi yang dianggap paling efektif dan prosesnya dapat dilakukan dengan cara yang sederhana.Komunikasi interpersonal dianggap efektif dan berhasil jika dalam interaksi tersebut pesan yang ingin disampaikan dapat diterima secara tepat oleh komunikan atau dengan kata lain, jika kebutuhan atau tujuan individu sudah tercapai. Salah satu faktor yang paling penting dalam keberhasilan komunikasi interpersonal adalah bagaimana kedua belah pihak yang terlibat dalam komunikasi memiliki pandangan atau memaknai pesan yang disampaikan oleh lawan komunikasinya.

Komunikasi interpersonal tidak hanya terjadi dalam kehidupan sehari-hari di tengah masyarakat, tetapi juga terjadi dalam suatu organisasi pendidikan. Dapat dilihat bahwa komunikasi interpersonal ini merupakan unsur yang paling penting dalam kelangsungan hubungan yang terjalin di dalam setiap organisasi pendidikan.

Setiap lembaga pendidikan (sekolah) membutuhkan dan melakukan komunikasi antara masing-masing pihak yang terlibat di dalam lembaga pendidikan tersebut. Komunikasi terjadi dalam setiap proses kegiatan, baik di lingkungan sekolah maupun di luar lingkungan sekolah. Muhammad dalam Harapan dan Ahmad (2014:61) menyatakan bahwa "berhasilnya suatu organisasi pendidikan dapat dilakukan bila dalam organisasi tersebut terjalin komunikasi antarpribadi yang berjalan efektif".

Pada umumnya pendidikan sangatlah penting bagi semua manusia di dunia. Semua berhak mendapatkan pendidikan, begitu juga dengan anak yang mengalami gangguan seperti anak autis. Karena tidak menutup kemungkinan, sebagian dari mereka memiliki inteligensi, bakat, dan kreativitas layaknya anak normal.

Berdasarkan angka kenaikan, pertumbuhan anak autis setiap tahunnya mengalami peningkatan. Maka dari itu pemerintah menyediakan sekolah khusus bagi mereka yang memiliki kemampuan 
"luar biasa" seperti anak autis yaitu Sekolah Luar Biasa (SLB). Maksud luar biasa disini yaitu menjelaskan tentang kemampuan lebih yang dimiliki anak autis disamping kekurangan yang mereka miliki. Sekolah khusus (SLB) ini sudah menyediakan tenaga ahli atau guru yang memang sudah terlatih dalam menangani anak-anak yang memiliki kebutuhan khusus seperti anak autis.

Menurut "Undang-Undang Nomor 20 Tahun 2003 tentang Sistem Pendidikan Nasional pasal 32 ayat 1" disebutkan bahwa pendidikan khusus merupakan pendidikan bagi peserta didik yang memiliki tingkat kesulitan dalam mengikuti proses pembelajaran karena kelainan fisik, emosional, mental, sosial, dan atau memiliki potensi kecerdasan dan bakat istimewa. Dalam Undang-Undang Nomor 20 Tahun 2003 ini juga menegaskan bahwa negara memberikan jaminan sepenuhnya kepada Anak Berkebutuhan Khusus (ABK) untuk mendapatkan kesempatan sama dengan anak lainnya dalam bidang pendidikan.

Dengan adanya bantuan baik itu pendidikan secara umum, pendidikan khusus, maupun pendidikan luar biasa, dalam masyarakat nantinya anak-anak tersebut dapat lebih mandiri dan mereka juga dapat mengembangkan potensi yang ada dan dimilikinya yang mungkin selama ini terpendam karena mereka belum bisa mandiri.

Dalam strategi komunikasi interpersonal di sekolah, secara aktif guru melakukan serangkaian pendekatan pada orang-orang terdekat siswa untuk mendapat informasi tentang kondisi siswa dan bagaimana kepribadian siswa sehariharinya. Sedangkan secara pasif, guru melakukan pengamatan atau observasi pada saat siswa beraktivitas baik di dalam maupun diluar kelas untuk mengetahui sejauh mana perkembangan siswa.
Penyandang autis dalam berkomunikasi dengan guru dan teman sesama autis di sekolah menggunakan dua jenis komunikasi, yaitu komunikasi satu arah dan komunikasi dua arah. Sedangkan ketika berada di luar sekolah penyandang autis hanya menggunakan pola komunikasi dua arah dengan orang tuanya. Komunikasi yang digunakan anak autis sangatlah unik karena berbeda dengan anak normal pada umumnya. Pola komunikasi yang digunakan anak autis dalam berkomunikasi dan berinteraksi dengan teman sesama autis, guru dan orang tua tergantung pada tingkat kemampuan dan spektrum autis yang dimiliki setiap anak.

Tidak semua anak autis memiliki IQ yang rendah, sebagian dari mereka memiliki kemampuan luar biasa di bidang tertentu, seperti dalam bidang musik, olahraga, menggambar, menari, melukis, matematika, dan sebagainya. Maka dari itu peran guru di sekolah sangat membantu dalam proses pengembangan bakat dan kreativitas mereka. Mereka lebih dituntut untuk mandiri dan mampu berinteraksi dengan orang lain ketika berada di sekolah.

Dalam pengembangan bakat dan kreativitas haruslah bertolak dari karakteristik keberbakatan dan kreativitas yang sudah ada dalam diri seorang individu yang meliputi ranah kognitif, afektif, dan psikomotor. Merupakan suatu tantangan bagi penyelenggara pendidikan khususnya bagi SLB dalam membina dan mengembangkan secara optimal bakat dan kreativitas yang ada dalam diri anak autis sehingga nantinya akan mewujudkan potensi diri sepenuhnya yang dapat bermanfaat dan juga dapat dijadikan bekal dalam menghadapi persaingan di kehidupan sosial dengan kekurangan dan kelebihan yang mereka miliki.

Berdasarkan observasi yang dilakukan di lapangan, terdapat beberapa masalah yang ditemukan yang dapat 
menghambat komunikasi interpersonal antara guru dan siswa autis dalam mengembangkan bakat dan kreativitas yaitu dari aspek komunikasi dan aspek emosional. Jika dilihat dari aspek komunikasi, sudah jelas terlihat bahwa siswa yang mengalami gangguan autis mengalami gangguan dalam berkomunikasi dan berinteraksi dengan orang lain. Mereka tidak mau berinteraksi dengan orang yang baru walaupun orang itu adalah guru mereka juga.

Dan jika dilihat dari aspek emosional, anak autis sering mengalami emosi yang tidak tentu. Kadang mereka menangis dan menjerit tanpa sebab, dan kadang pula mereka tertawa. Hal inilah yang membuat para guru kesulitan dalam menangani dan memahami mereka.

Perumusan masalah yang terdapat dalam penulisan ini yaitu bagaimana komunikasi interpersonal guru dan siswa dalam mengembangkan bakat \& kreativitas anak autis di SLB TPI Medan, serta faktor apa saja yang mempengaruhi munculnya bakat dan kreativitas pada anak autis.

Berdasarkan perumusan masalah yang ada di dalam penulisan ini, maka tujuan dari penulisan ini yaituuntuk mengetahui komunikasi interpersonal guru dan siswa dalam mengembangkan bakat \& kreativitas anak autis di SLB TPI Medan, serta untuk mengetahui faktor apa saja yang mempengaruhi munculnya bakat dan kreativitas pada anak autis.

\section{METODOLOGI PENELITIAN}

Metode yang digunakan dalam penelitian ini adalah pendekatan kualitatif. Hasil dalam penulisan ini berupa data yang berbentuk kata, kalimat, dan narasi.

Sumber data dalam penulisan kualitatif disesuaikan dengan fokus dan tujuan penulisan. Sesuai dengan fokus penulisan, maka yang dijadikan sumber data atau informan dalam penulisan ini yaitu orangtua dan guru yang membimbing serta mengajari anak-anak autis di SLB TPI Medan.

Dalam penelitian ini, metode snowball sampling yang digunakan untuk mendapatkan informan/sumber data yaitu pertama-tama penulis menemui guru yang berada di bagian administrasi sekolah untuk memberikan surat izin penulisan. Setelah itu guru tersebut mengarahkan penulis untuk menemui guru yang mengajari anak autis. Setelah mendapatkan data dan informasi dari guru, penulis masih memerlukan data dan informasi dari orangtua siswa autis tersebut. Maka dari itu penulis menemui orangtua siswa autis untuk melengkapi data dan informasi yang dibutuhkan dalam penelitian.

Lokasi penelitian adalah Sekolah Luar Biasa Taman Pendidikan Islam (SLBTPI) Medan, yang terletak di Jl. SM. Raja Km.7 No.5 Medan mulai dari tanggal 14 April 2016 - 2 Juni 2016.

Teknik pengumpulan data yang digunakan penulis yaitu observasi, wawancara mendalam, dan dokumentasi.

Pada saat observasi, penulis melakukan observasi langsung terhadap komunikasi interpersonal yang terjadi pada siswa autis dan membuat lembar observasi. Pada lembar observasi, penulis membuat hasil dari pengamatan yang dilakukan selama penulisan berlangsung, seperti cara berinteraksi, sikap anak autis, dan cara guru memberikan pengajaran kepada anak autis selama di kelas.

Pada saat melakukan wawancara mendalam, penulis mewawancarai 4 orang informan yaitu 2 orangtua dari anak autis dan 2 orang guru yang membimbing serta mengajari anak-anak autis di SLB TPI Medan. Penulis memberikan beberapa pertanyaan untuk mendapatkan data atau informasi yang kemudian dapat diolah menjadi hasil penulisan. 
Untuk mendukung analisis dan interpretasi data, penulis juga menambahkan dokumentasi pada saat melakukan penulisan. Penulis mengambil dokumentasi berupa foto, lembar observasi, dan rekaman suara selama proses observasi dan wawancara terhadap informan berlangsung.Dalam penelitian ini, penulis menggunakan teknik analisis data model Miles dan Huberman, yaitu reduksi data, penyajian data,menarik kesimpulan dan verifikasi.

\section{HASIL DAN PEMBAHASAN}

Dalam melakukan komunikasi interpersonal, terdapat beberapa aspek yang dapat mempengaruhi keberhasilan komunikasi interpersonal tersebut. Setelah melakukan penulisan terhadap komunikasi interpersonal guru dan siswa dalam mengembangkan bakat dan kreativitas siswa autis di SLB Taman Pendidikan Islam Medan, maka penulis dapat mengaitkan hasil penulisan dengan teori De Vito dalam Liliweri (1997), yaitu ada beberapa aspek yang harus diperhatikan oleh pelaku komunikasi interpersonal:

1. Keterbukaan (openness)

Keterbukaan yaitu keinginan untuk membuka diri dalam hal berinteraksi dengan orang lain. Penulis dapat melihat bahwa antara guru dan siswa autis sudah terbangun komunikasi interpersonal yang bersifat terbuka dan penuh kasih sayang antara satu sama lain karena di antara mereka sudah terbangun chemistry yang erat. Siswa autis merasa sangat percaya dengan masing-masing guru yang mengajarinya, mereka mematuhi perintah yang diberikan oleh gurunya. Mereka juga sudah merasa nyaman dengan guru yang mengajari mereka saat ini.

\section{Empati (empathy)}

Empati diartikan sebagai kemampuan untuk mengetahui apa yang dirasakan oleh orang lain. Dalam hal ini, masing-masing informan dalam penulisan ini bisa dikatakan kurang memiliki rasa empati terhadap orang lain. Bukan berarti mereka sama sekali tidak peduli dengan apa yang dirasakan orang lain, tetapi tingkat kepekaannya yang masih terbilang kurang jika dibandingkan anak normal lainnya. Tetapi jika dibandingkan antara kedua informan penulisan ini, Kurnia memiliki rasa sosialisasi yang lebih dibandingkan dengan Afgan. Terlihat dari pola asuh yang diberikan oleh orangtuanya. Kurnia dibebaskan untuk berinteraksi dengan orang-orang di lingkungan sekitarnya, sedangkan Afgan tidak dibebaskan oleh orangtuanya untuk berinteraksi dengan orang-orang di lingkungan sekitarnya. Namun rasa empati ini masih bisa terus ditingkatkan dengan cara mengajarkan mereka untuk terus bersosialisasi dan berinteraksi dengan orang lain sehingga mereka dapat merasakan apa yang sedang dirasakan oleh orang lain.

\section{Dukungan (supportiveness)}

Dalam hal ini, dukungan yang dibutuhkan oleh anak autis yaitu dukungan moral yang diberikan oleh keluarga dan guru. Dengan adanya dukungan dari orangorang terdekatnya, maka proses komunikasi interpersonal yang terjalin dalam mengembangkan bakat dan kreativitas anak autis dapat memberikan respon yang positif dan membuat mereka merasa percaya diri karena mereka merasa banyak orang yang peduli dan sayang kepada mereka walaupun dengan kekurangan yang mereka miliki.

\section{Perasaan positif (positiveness)}

Sikap positif dalam komunikasi interpersonal berarti bahwa kemampuan seseorang dalam memandang dirinya secara positif dan dapat menghargai orang lain. 
Sikap positif yang ditunjukkan guru terhadap siswa autis dalam komunikasi interpersonal yang terjalin di antara mereka yaitu dengan memberikan perhatian dan kasih sayang yang khusus kepada mereka serta memberikan pujian ataupun penghargaan ketika siswa autis melakukan hal-hal positif yang bermanfaat.

\section{Kesamaan (equality)}

Kesamaan berarti kita dapat menerima dan merasa sama dengan orang lain. Dalam hal ini, guru harus memposisikan dirinya sebagai teman dekat dari siswa autis. Mereka harus bisa menciptakan komunikasi interpersonal yang baik. Guru sebagai seorang pendidik sudah mengabdi untuk membimbing dan mengarahkan siswa autis agar bisa menjadi orang yang bermanfaat bagi orang lain. Komunikasi yang dibangun tidak lepas dari rasa kasih sayang, saling keterbukaan, dan rasa kepercayaan antara satu sama lain.

Dari komunikasi interpersonal yang terjalin antara guru dan siswa autis, maka sudah terbangun kedekatan emosi di antara mereka. Dengan terbangunnya kedekatan emosi tersebut maka lebih mudah bagi guru untuk memahami karakteristik anak didik mereka masing-masing. Mereka juga sudah mengetahui trik/cara-cara yang dapat dilakukan untuk menghadapi emosi anak autis yang tidak tentu, mulai dari bagaimana cara agar membuat anak autis fokus dalam belajar, cara menjaga kestabilan emosi dan mood anak autis, serta metode pengajaran yang tepat dilakukan di dalam kelas.

Berdasarkan penulisan yang dilakukan, pada bagian ini penulis membahas tentang apa saja trik/cara yang dilakukan oleh guru di SLB TPI Medan dalam menghadapi anak autis ketika berada di sekolah.
1. Cara membuat anak autis fokus dalam belajar

Ada beberapa teknik yang dilakukan guru untuk membuat anak autis fokus dan giat dalam belajar:

a. Menggunakan bahasa yang sederhana

Bahasa adalah pengantar ampuh untuk menyampaikan segala sesuatu. Dengan bahasa dan sikap yang sederhana maka orang lain akan suka dengan apa yang kita sampaikan. Begitu juga dengan anak autis, mereka tidak akan merasa bosan dan tetap fokus dengan apa yang gurunya sampaikan jika menggunakan bahasa yang sederhana, karena bahasa tersebut mudah dipahami oleh mereka.

Berdasarkan observasi yang penulis lakukan, dalam menyampaikan perintah atau pelajaran kepada anak autis guru menggunakan bahasa atau kalimat yang pendek. Kalimat tersebut disampaikan dengan suara yang kuat dan dengan cara berulang-ulang. Karena memang tidak mudah untuk menarik perhatian anak autis agar bisa mendengarkan apa yang gurunya sampaikan. Maka dari itu, guru menggunakan suara yang kuat tetapi tidak bersifat kasar.

b. Membiarkan mereka memiliki gaya belajar sendiri

Dengan membiarkan mereka memiliki gaya belajar sendiri, itu memungkinkan mereka untuk lebih cepat menyerap setiap informasi atau perintah yang disampaikan. Guru harus mengetahui gaya belajar seperti apa yang disukai anak autis agar mereka bisa fokus pada apa yang diajarkan. Anak autis cenderung kehilangan minat bila mereka tidak mengerti dan tidak menyukai apa yang diajarkan. Jika dilihat dari kedua informan penulisan, masing-masing dari mereka lebih menyukai cara belajar dengan visual (menggunakan gambar atau alat peraga), meniru, dan menghafal. Masing- 
masing guru memiliki cara sendiri dalam menangani anak didik mereka.

Pada informan pertama, guru menunjukkan langsung jenis tumbuhan ketika sedang belajar IPA (Sains). Ketika sedang berlatih membaca puisi dan menghafal surah-surah Al-Quran, guru memberikan contoh terlebih dahulu kemudian Kurnia akan menghafal dan membacakannya kembali. Seperti dalam hal belajar membaca puisi, cara yang dilakukan guru yaitu merekam suaranya lalu memperdengarkannya kepada Kurnia. Dari rekaman itulah, Kurnia dapat meniru dan belajar bagaimana cara berbicara menggunakan intonasi suara yang baik untuk membaca puisi.

Pada informan kedua, guru menggunakan alat peraga "scrable" untuk membantu mengenalkan angka dan huruf kepada Afgan. Guru juga menunjukkan bola dengan berbagai warna untuk melatih agar Afgan dapat mengingat dan mengetahui jenis warna. Ketika sedang belajar menghafal nama-nama hari, guru menyuruh Afgan untuk menghafal lalu menuliskannya kembali di bukunya.

2. Cara menjaga kestabilan emosi dan mood anak autis

Masing-masing guru memiliki cara sendiri untuk menjaga kestabilan emosi dan mood anak didiknya.

a. Menanyakan langsung masalah yang mengganggu emosi dan mood nya

Cara ini dilakukan oleh guru yang mengajari Kurnia. Menurut gurunya jika Kurnia mengalami gangguan mood ketika datang ke sekolah, pasti ada sesuatu yang membuat dia merasa tidak enak ketika berada di rumah. Maka dari itu, cara yang tepat dilakukan oleh gurunya yaitu menghubungi orangtuanya dan menanyakan keadaan Kurnia sebelum berangkat ke sekolah, apakah ada sesuatu yang membuat dia merasa kesal ataupun tidak nyaman. Bisa juga gurunya menanyakan langsung kepada Kurnia apa yang sedang dirasakan dan dikeluhkannya, karena terkadang Kurnia juga mau memberitahu langsung dan bersifat terbuka kepada gurunya walaupun dia menyampaikan semua itu dengan bahasa atau kalimat yang sulit dipahami. Setelah mengetahui masalah yang mengganggu emosi dan mood Kurnia, barulah guru mencoba menenangkan dan memberikan pengertian kepadanya.

b. Memberikan reward dan punishment

Pemberian reward dan punishment berkaitan dengan teori belajar Operant Conditioning yang dikemukakan oleh Skinner (1904). Teori ini menjelaskan perubahan tingkah laku seseorang dipengaruhi oleh suatu penguat (reinforcement). Reinforcement dapat bersifat positif dan bisa juga negatif. Reinforcement positif yaitu peristiwa atau sesuatu yang membuat tingkah laku seseorang yang dikehendaki berpeluang untuk diulang atau terjadi lagi. Sebaliknya, reinforcement negatif yaitu peristiwa atau sesuatu yang membuat tingkah laku seseorang yang dikehendaki berpeluang untuk diulang menjadi lebih kecil. Dalam hal ini, pemberian hadiah (reward) berperan sebagai reinforcement positif, dan pemberian hukuman (punishment) berperan sebagai reinforcement negatif.

Cara ini dilakukan oleh guru yang mengajari Afgan. Dalam menghadapi sikap Afgan ketika sedang malas atau tidak mood belajar, cara yang dilakukan oleh gurunya yaitu memberikan reward dan punishment. Hal ini dapat memperbaiki mood dan kondisinya agar mau kembali belajar.

Reward adalah bentuk penghargaan yang diberikan kepada seseorang ketika melakukan pekerjaan dengan baik dan benar. Sedangkan punishment adalah bentuk hukuman yang diberikan kepada seseorang ketika tidak bisa melakukan 
pekerjaan dengan baik dan benar. Dalam hal ini, guru memberikan reward kepada Afgan berupa hadiah yaitu permen. Biasanya Afgan paling malas jika disuruh menulis oleh gurunya, jadi apabila Afgan sudah mulai merasa malas maka gurunya pun memberikan hadiah berupa permen kepadanya. Dan jika Afgan masih malas dan tidak mau menyelesaikan tugasnya, maka gurunya memberikan punishment seperti menutup pelajaran dan menyuruh Afgan pulang. Afgan merupakan anak yang senang ketika berada di sekolah, jadi jika gurunya memberikan punishment seperti itu Afgan langsung menyelesaikan tugasnya dengan baik dan benar karena dia tidak mau menerima punishment seperti itu. Setelah selesai mengerjakan tugas, barulah dia mendapatkan reward yang sudah dijanjikan kepadanya.

\section{Metode pengajaran di dalam kelas}

Metode pengajaran efektif yang dilakukan guru terhadap anak autis di dalam kelas yaitu:

\section{a. Isyarat visual / verbal}

Isyarat visual / verbal adalah bentuk pengajaran yang diberikan kepada anak autis untuk membantu mereka melengkapi tugas-tugas yang diinginkan. Bentuk pengajaran ini bisa dilakukan dengan cara verbal maupun non verbal, dengan menggunakan tanda-tanda atau strategi visual. Strategi visual merupakan strategi pembelajaran dengan menggunakan benda, gambar, atau simbol dalam menyampaikan pembelajaran.

Pada informan kedua, guru menggunakan bantuan benda-benda seperti bola berwarna untuk membantu menjelaskan jenis-jenis warna, scrable untuk membantu mengenalkan huruf dan angka, serta menunjukkan gambar-gambar seperti rumah, mobil, pesawat, dsb. Benda dan gambar tersebut digunakan untuk mempermudah proses pembelajaran agar Afgan lebih mudah memahami. Penggunaan benda atau gambar dengan bentuk dan warna yang menarik akan membuat Afgan lebih bersemangat untuk belajar dan tidak cepat merasa bosan.

b. Pemodelan / meniru

Pemodelan merupakan strategi pembelajaran yang menggunakan orangorang di sekitar sebagai model seperti orangtua, guru, atau teman sebaya, terutama ketika mengajarkan keterampilanketerampilan baru kepada anak autis.

Pada informan pertama, yang dijadikan sebagai model dalam proses pembelajaran yaitu guru. Ketika melatih Kurnia membaca puisi dan menghafal surah-surah Al-Quran guru memberikan contoh terlebih dahulu, bagaimana penyebutan kata-kata, intonasi, dan suara yang harus dibuat agar bisa mendapatkan hasil yang baik. Guru merekam suaranya setelah itu diberikan kepada Kurnia agar bisa terus diingat dan dihafal di dalam memori otaknya. Model pengajaran seperti ini dianggap cukup efektif dilakukan terhadap Kurnia. Terbukti sekarang dia sudah bisa membaca puisi dengan intonasi dan suara yang pas, serta mampu menghafal beberapa surah-surah dalam Al-Quran.

Dalam proses pengembangan bakat dan kreativitas anak autis, peran komunikasi interpersonal memang sangat dibutuhkan, baik antara guru dengan anak autis ataupun antara orangtua dengan anak autis. Namun selain itu, ada juga beberapa faktor yang dapat mempengaruhi munculnya bakat pada anak autis yaitu:

1. Faktor Internal, yaitu faktor yang berasal dari dalam diri anak yang terdiri atas:

a. Faktor bawaan (genetik)

Berdasarkan penulisan yang telah dilakukan, menurut penulis memang benar adanya faktor bawaan (genetik) pada bakat yang ditunjukkan oleh masing-masing 
informan. Jika dilihat pada informan pertama, bakat membaca dan menghafal surah-surah pendek dalam Al-Qur'an memang ditunjukkan ada hubungannya dengan faktor bawaan dari keluarganya, karena informan pertama terlahir dari keluarga yang memiliki latar belakang agama yang cukup kuat.

Jika dilihat pada informan kedua, bakat menggambar dan mewarnai juga merupakan faktor bawaan dari keluarganya. Ayah dari informan kedua juga mempunyai bakat yang sama yaitu menggambar. Banyak gambar yang sudah dibuat oleh ayahnya lalu setelah itu diwarnai oleh informan kedua.

\section{b. Faktor kepribadian}

Faktor ini merupakan keadaan psikologis seorang anak dimana perkembangan potensinya tergantung pada diri dan emosi yang dimilikinya yang dapat berwujud minat, motivasi, dan dorongan yang ada dalam dirinya. Jika dilihat dari minat dan kesukaannya, masing-masing informan memiliki minat yang berbeda. Informan pertama mempunyai minat dan bakat dalam hal membaca puisi dan AlQur'an, sedangkan informan kedua mempunyai minat dan bakat dalam hal menyanyi, menggambar, dan mewarnai.

2. Faktor Eksternal, yaitu faktor yang berasal dari luar diri anak yang terdiri atas:

\section{a. Lingkungan keluarga}

Lingkungan keluarga merupakan faktor yang sangat dominan karena anak autis membutuhkan pengawasan dan perhatian yang lebih dalam hal mendidiknya. Seluruh anggota keluarga harus menunjukkan sikap memahami dan peduli terhadap pikiran dan perasaan anak autis, bersikap terbuka dan memberikan peluang kepada mereka untuk mengekspresikan diri dan mengeksplor bakat dan kreativitas yang ada dalam dirinya, serta selalu mendukung apapun yang menjadi kesukaan atau hobi anakanaknya jika itu bersifat positif.

Seperti halnya yang dilakukan oleh kedua orangtua dari masing-masing informan dalam penulisan ini. Mereka memberikan dukungan, perhatian, kasih sayang, dan juga menyediakan media untuk mengembangkan bakat dan kreativitas yang dimiliki masing-masing anaknya.

Pada informan pertama, orangtua melihat bakat membaca puisi dan menghafal Al-Quran yang ada pada anaknya. Orangtua bekerjasama dengan guru untuk terus mengasah kemampuan dan bakat yang ada pada diri anaknya. Dengan dukungan dan kasih sayang yang diperoleh anak dari seluruh anggota keluarganya, maka dia juga akan lebih termotivasi lagi untuk bersemangat dalam mengembangkan bakat yang dimilikinya.

Pada informan kedua, orangtua melihat kegemaran anaknya dalam hal menggambar dan mewarnai. Maka dari itu, orangtua memberikan dukungan yang positif kepada anaknya dengan memberikan media berupa kertas dan alat tulis mewarnai untuk mengembangkan bakat dan kreativitas yang dimiliki anaknya.

b. Lingkungan sekolah

Lingkungan sekolah merupakan faktor yang juga dapat menjadi penentu perkembangan bakat dan kreativitas anak autis karena di lingkungan ini bakat dan kreativitas anak autis dapat dikembangkan secara intensif. Di lingkungan ini juga mereka bisa lebih bersosialisasi dan berkomunikasi dengan orang lain seperti guru dan teman sebayanya. Hal inilah yang dapat meningkatkan rasa percaya diri pada anak autis sehingga mereka tidak merasa malu atau minder dengan kekurangan mereka.

Jika dilihat pada informan pertama, dia sering menampilkan kemampuannya dalam hal membaca puisi dan menghafal 
surah-surah Al-Quran ketika berada di sekolah. Di setiap acara di sekolah, gurunya selalu menyuruhnya untuk tampil di depan umum. Pada informan kedua, bakat dan kreativitasnya juga sering diperlihatkan di kelas. Setiap selesai menggambar dan mewarnai, maka hasil dari kreativitasnya tersebut ditempelkan di papan tulis yang berisi hasil kreativitas dari anak-anak autis.

\section{KESIMPULAN}

Adapun hasil yang dapat penulis simpulkan dalam penulisan ini yaitu sebagai berikut:

1. Jika dilihat dari komunikasi interpersonal yang terjadi antara guru dengan siswa autis, masing-masing informan penulisan mempunyai kedekatan yang sangat erat dengan masing-masing gurunya karena dalam proses belajar mereka hanya diajarkan oleh satu orang guru saja. Hal ini yang membuat chemistry di antara mereka semakin erat dan keterbukaan komunikasi yang terjalin cukup baik layaknya orangtua dan anak. Komunikasi interpersonal yang terjalin di antara mereka didukung dengan adanya rasa keterbukaan, kasih sayang, dan saling percaya antara satu sama lain. Peran guru di sekolah sangat membantu orangtua dalam mengembangkan bakat dan kreativitas yang dimiliki anak autis. Orangtua sepenuhnya mempercayakan kepada guru untuk bisa membantu perkembangan anaknya, baik dalam hal komunikasi maupun perkembangan yang lainnya seperti sosialisasi, rasa percaya diri, dan lain-lain.

2. Faktor-faktor yang mempengaruhi munculnya bakat dan kreativitas pada anak autis yaitu:

1) Faktor internal

a. Faktor bawaan (genetik)

Munculnya bakat dan kreativitas pada anak autis juga dipengaruhi oleh faktor bawaan (genetik). Pada informan pertama, bakat membaca dan menghafal surahsurah pendek dalam Al-Qur'an ditunjukkan ada hubungannya dengan faktor bawaan dari keluarganya, karena informan pertama terlahir dari keluarga yang memiliki latar belakang agama yang cukup kuat. Pada informan kedua, bakat menggambar dan mewarnai juga merupakan faktor bawaan dari

keluarganya. Ayah dari informan kedua mempunyai bakat yang sama yaitu menggambar.

b. Faktor kepribadian

Faktor kepribadian merupakan keadaan psikologis anak yang dapat berwujud minat, motivasi, dan dorongan yang ada dalam dirinya. Berdasarkan minat yang dimiliki masing-masing informan, bakat dan kreativitas yang dimiliki informan pertama yaitu membaca puisi dan menghafal surah-surah yang ada di dalam Al-Qur'an, sedangkan pada informan kedua bakat dan kreativitas yang dimiliki yaitu menyanyi, menggambar, dan mewarnai.

Perkembangan bakat dan kreativitas anak autis juga dipengaruhi oleh umur dari masing-masing informan. Terlihat pada informan pertama (Kurnia) yang berumur 16 tahun memiliki bakat dan kreativitas yang lebih matang dibandingkan dengan informan kedua (Afgan) yang berumur 8 tahun. Bakat dan kreativitas yang dimiliki oleh informan kedua masih perlu dikembangkan lagi agar bisa mendapatkan hasil yang maksimal.

2) Faktor eksternal

a. Lingkungan keluarga

Dukungan dari keluarga dapat mempengaruhi perkembangan komunikasi serta bakat dan kreativitas yang dimiliki 
oleh siswa autis. Seperti dengan memberikan media atau alat yang dapat membantu proses pengembangan bakat dan kreativitas tersebut.

Pola asuh dan komunikasi yang terjadi di dalam lingkungan keluarga juga dapat mempengaruhi perkembangan pada anak autis. Terlihat dari pola asuh yang diberikan orangtua informan pertama (Kurnia) yang membebaskan anaknya untuk berinteraksi dengan lingkungan sekitar dapat membantu meningkatkan kepercayaan diri dan rasa peduli terhadap lingkungan sekitarnya. Untuk informan kedua (Afgan), pola asuh yang diberikan berbeda dengan informan pertama. Pada informan kedua, orangtua tidak membebaskan anaknya untuk berinteraksi dengan lingkungan sekitarnya, sehingga membuat sosialisasi informan kedua terhadap lingkungan sekitar bisa dikatakan kurang baik.

b. Lingkungan sekolah

Lingkungan sekolah merupakan faktor yang juga dapat menjadi penentu perkembangan bakat dan kreativitas anak autis karena di lingkungan ini bakat dan kreativitas anak autis dapat dikembangkan secara intensif. Pada informan pertama, setiap ada acara di sekolah Kurnia sering menampilkan kemampuannya dalam hal membaca puisi dan menghafal surahsurah Al-Quran di depan umum. Hal ini juga dapat meningkatkan kepercayaan dirinya ketika tampil di depan orang banyak. Pada informan kedua, bakat dan kreativitasnya juga sering diperlihatkan di kelas. Hasil dari gambar yang sudah diwarnainya, ditempelkan di papan tulis yang berisi hasil kreativitas dari anakanak autis.

Dari simpulan yang telah didapat, maka penulis ingin memberikan beberapa saran ataupun masukan yang nantinya bisa memberikan manfaat. Adapun saran yang ingin disampaikan oleh penulis yaitu sebagai berikut:

1. Diharapkan kepada pemerintah, Lembaga Swadaya Masyarakat (LSM), dan aktivis peduli autisme, agar memberikan sosialisasi mengenai autisme kepada masyarakat yang belum mengerti, sehingga nantinya penanganan yang diberikan tidak salah dan proses perkembangan dalam diri anak autis bisa berjalan dengan baik dan efektif. Disarankan juga kepada pemerintah, LSM, maupun aktivis peduli autisme untuk menyediakan beberapa SLB ataupun "rumah singgah" beserta pendidiknya di berbagai daerah, khususnya di kota-kota kecil untuk menjangkau anak-anak autis yang berada di kota-kota kecil tersebut.

2. Diharapkan untuk guru agar terus menjalin kedekatan dan komunikasi yang baik dengan masing-masing siswa autis. Tidak hanya kepada siswa yang mereka ajarkan saja, tetapi kepada seluruh siswa autis yang ada di SLB TPI Medan sehingga dalam hal pengembangan bakat dan kreativitas, guru bisa lebih mudah mengetahui bakat dan kreativitas apa saja yang ada pada diri anak autis dan menentukan caracara untuk mengembangkan bakat dan kreativitas tersebut.

3. Sebaiknya bakat dan kreativitas anak autis sudah mulai dideteksi atau dicari tahu mulai dari mereka kecil sehingga proses pengembangan bakat dan kreativitas tersebut bisa berjalan dengan mudah dan mendapatkan hasil yang maksimal.

4. Setelah mengetahui bakat dan kreativitas yang dimiliki oleh anaknya, sebaiknya orangtua memberikan pelayanan dan perhatian khusus untuk mengasah kemampuan yang dimiliki oleh anaknya, seperti mendaftarkan mereka ke tempat kursus yang sesuai dengan bakat dan 
kreativitas yang mereka miliki. Karena pada dasarnya, kemampuan dan keterampilan itu penting untuk masa depan mereka.

5. Untuk mewujudkan komunikasi interpersonal yang baik antara anak autis dengan orang-orang di sekitarnya, sebaiknya orangtua membiarkan mereka untuk bisa bersosialisasi dengan banyak orang supaya rasa kepedulian dan percaya diri mereka terhadap orang lain tumbuh layaknya anak normal lainnya.

6. Kompetensi guru dalam mendidik dan mengajari siswa autis agar lebih ditingkatkan lagi untuk memahami kebutuhan dan keinginan siswa autis di SLB Taman Pendidikan Islam. Dalam hal ini guru dituntut untuk menjalin hubungan yang lebih bersahabat dan dekat dengan siswa autis agar keterbukaan komunikasi antara guru dan siswa autis dapat terjalin dengan baik dan lancar.

7. Pengembangan bakat dan kreativitas yang dilakukan di sekolah harus lebih intensif, misalnya dengan membuka kelas khusus bagi anak-anak yang memiliki bakat dan kreativitas.

\section{DAFTAR PUSTAKA}

Budyatna, Muhammad., dan Leila Mona Ganiem. 2011. Teori Komunikasi Antarpribadi. Jakarta: Kencana.

Danuatmaja, Bonny. 2003. Terapi Anak Autis di Rumah. Jakarta: Puspa Swara.

Harapan, Edi., dan Syarwani Ahmad. 2014. Komunikasi Antarpribadi: PerilakuInsani dalam Organisasi Pendidikan. Jakarta: Rajawali Pers Kriyantono, Rachmat. 2010. Teknik Praktis Riset Komunikasi. Jakarta: Kencana
Liliweri, Alo. 1997. Komunikasi Antarpribadi. Bandung: Citra Aditya Bakti.

Maulana, Mirza. 2014. Anak Autis: Mendidik Anak Autis dan Gangguan Mental Lain Menuju Anak Cerdas dan Sehat. Jogjakarta: Katahati.

Reefani, Nur Kholis. 2013. Panduan Mendidik Anak Berkebutuhan Khusus. Yogyakarta: Imperium.

Safaria, Triantoro. 2005. AUTISME: Pemahaman Baru untuk Hidup Bermakna Bagi Orangtua. Yogyakarta: Graha Ilmu.

Somantri, Sutjihati. 2006. Psikologi Anak Luar Biasa. Bandung: PT. Refika Aditama.

Syah, Muhibbin. 2011. Psikologi Belajar. Jakarta: Rajawali Pers.

Sumber Lain

Undang-Undang Nomor 20 Tahun 2003 tentang Sistem Pendidikan Nasional pasal 32 ayat 1. 